\title{
Acute renal failure due to severe hypercalcemia and nephrocalcinosis treated with two doses of pamidronate in an infant with Williams-Beuren syndrome
}

\author{
Funda Baştuğำ, Hülya Nalçacıoğlư ${ }^{1}$, Veysel Nijat Baş², Binnaz Tekatlı-Çelik ${ }^{3}$, \\ Hasan Çetinkaya ${ }^{3}$, Sibel Yel ${ }^{1}$ \\ Departments of ${ }^{1}$ Pediatric Nephrology, ${ }^{2}$ Pediatric Endocrinology and ${ }^{3}$ Pediatrics, Kayseri Training and Research Hospital, \\ Kayseri, Turkey. E-mail: hulyanalcacoglu@hotmail.com \\ Received: 6th December 2016, Revised: 17th February 2017, 24th May 2017, Accepted: 30th June 2017
}

\begin{abstract}
SUMMARY: Baştuğ F, Nalçacıoğlu H, Baş VN, Tekatlı-Çelik B, Çetinkaya H, Yel S. Acute renal failure due to severe hypercalcemia and nephrocalcinosis treated with two doses of pamidronate in an infant with Williams-Beuren syndrome. Turk J Pediatr 2018; 60: 210-215.

Infantile hypercalcemia has been reported in $15 \%$ of infants and children with Williams-Beuren syndrome (WBS) and has generally mild clinical symptoms. However, the need for pamidronate treatment in a few infants with severe hypercalcemia associated with WBS has been reported in literature. Many disorders, such as primary hyperoxaluria, associated with nephrocalcinosis can lead to renal failure, but there are only a few reports in infants with WBS who have decreased renal function and nephrocalsinosis. We present a 23-month-old girl with WBS (confirmed with fluorescent in situ hybridization probes) who presented with acute renal failure with severe symptomatic hypercalcemia and nephrocalcinosis, which responded to two infusions of pamidronate.
\end{abstract}

Key words: hypercalcemia, renal failure, pamidronate, Williams-Beuren syndrome.

Williams-Beuren syndrome (WBS) is an autosomal dominant disorder characterized by infantile hypercalcemia, persistent growth failure, mild mental retardation, cardiovascular abnormalities, distinctive behavioral characteristics including irritability, overfriendliness and characteristic facial appearance include large lips, flat nasal bridge, epicanthal folds, long philtrum, and abnormal teeth. ${ }^{1,2}$ Cardiovascular anomalies such as supravalvular aortic stenosis occur in $80 \%$ of the patients with WBS. ${ }^{3}$ An episode of hypercalcemia in infancy is typically mild and transient usually occurring in the first years of life. ${ }^{4}$ Pamidronate has been used in the treatment of childhood hypercalcemia, but there are only a few reports in the literature regarding the use of bisphosphonates in the treatment of WBS-associated hypercalcemia. ${ }^{5-8}$

The estimated incidence of renal abnormalities in WBS is $18 \%$. Congenital structural renal defects include ectopia, agenesis, hypoplasia, duplication, hydronephrosis, vesicoureteral reflux, and stenosis of the renal artery. Renal involvement can also be present as nephrocalcinosis, proteinuria and chronic renal insufficiency. ${ }^{9}$ Transient decreased renal function secondary to severe hypercalcemia and nephrocalcinosis has been encountered in only one infant in the literature. ${ }^{9}$ We report an infant with WBS who presented with acute renal failure associated with severe symptomatic hypercalcemia and nephrocalcinosis which was successfully treated with two infusions of pamidronate.

\section{Case Report}

A girl aged 23 months was admitted to our clinic for the investigation of medullary nephrocalcinosis. She presented with an 8-month history of increasing irritability, sleep dysregulation, restless legs, feeding problems and decreased weight gain. We learned that she had been diagnosed as having mental and growth retardation and being a syndromic baby due to having an abnormal 
face appearance and nephrolithiasis since she was 10 months (no document was provided for detailed description); she was being treated with potassium citrate solution. The patient was born via cesarean section and as one of fraternal twins at 38 weeks of gestation. Her birth weight was 2050 g. She was breast-fed until 2 months, then her diet consisted of only formula. She was neither walking nor speaking at 23 months. Her parents first became concerned about her development around the age of 13 months, when they noticed that her physical development was "slow." She rolled over at 9 months, sat alone without support at approximately 12 months, crawled at 18-20 months. She also showed significant delays in communication; expressive language was severely delayed with rare speech (a few words) and limited sign language and receptive language at $<1$ year of age. She had healthy parents who had no consanguinity. The other twin was healthy and there was no history of specific diseases in the family. On admission, her body weight was 7,500 g (SDS: -3.99), length was $74 \mathrm{~cm}$ (SDS: -3.68), and head circumference was $43 \mathrm{~cm}$ ( $<3$ rd percentile for age). A physical examination revealed fever but her heart rate, blood pressure and respiratory rate were normal. She had the characteristic facial appearance of WBS, i.e., elongated philtrum, low nasal bridge, broad nasal tip, eyes set apart, periorbital fullness, wide mouth, widely spaced teeth, the so-called elfin face (Fig. 1). She also had mild mental retardation, hypotonia and hyperextensible joints of lower extremities. A grade II ejection systolic murmur was audible in the cardiovascular system examination. At her initial examination 2 months previously, the laboratory tests results were: serum calcium $(\mathrm{Ca}) 11.1 \mathrm{mg} / \mathrm{dl}$ (normal: 8.5-10.6 mg/dl), blood urea nitrogen (BUN) $12 \mathrm{mg} / \mathrm{dl}$ (normal: 7-20 mg/dl), and creatinine (Cr) $0.7 \mathrm{mg} / \mathrm{dl}$ (normal: 0.39-0.55 mg/dl).

On admission, the laboratory results on admission were as follows: hemoglobin, 11.2 $\mathrm{g} / \mathrm{dl}$; total white blood cell count, 6,500/ $\mathrm{mm}^{3}$; platelet count, $327,000 / \mathrm{mm}^{3}$; sodium, $137 \mathrm{mEq} / \mathrm{l}$; potassium, $4.5 \mathrm{mEq} / \mathrm{L}$; chloride, $97 \mathrm{mEq} / \mathrm{L} ;$ BUN $38 \mathrm{mg} / \mathrm{dl}, \mathrm{Cr} 1.7 \mathrm{mg} / \mathrm{dl}$, uric acid, $5.6 \mathrm{mg} / \mathrm{dl}$, calcium, phosphorus, and alkaline phosphatase were found as 16 $\mathrm{mg} / \mathrm{dl}, 4.2 \mathrm{mg} / \mathrm{dl}$, and $191 \mathrm{IU} / \mathrm{L}$, respectively. Venous $\mathrm{pH}$ was 7.44 ; pCO2, $38.5 \mathrm{mmHg}$; $\mathrm{HCO} 3,23 \mathrm{mEq} / \mathrm{L}$; base excess, $2 \mathrm{mEq} / \mathrm{L}$. Urinalysis revealed a $\mathrm{pH}$ of 6.5 , protein of $30 \mathrm{mg} / \mathrm{dl}$, and hyposthenuria (urine density: 1005) on the dipstick. In the renal tubular function tests, the results were found: urine output $2.8 \mathrm{ml} / \mathrm{kg} /$ hour, fractional excretion of sodium $2.3 \%$, and tubular reabsorption of phosphorus $65 \%$. Urinary protein excretion was $7 \mathrm{mg} / \mathrm{m}^{2}$ per hour (normal $<4 \mathrm{mg} / \mathrm{m}^{2}$ per hour), calcium excretion $18 \mathrm{mg} / \mathrm{kg} / 24$
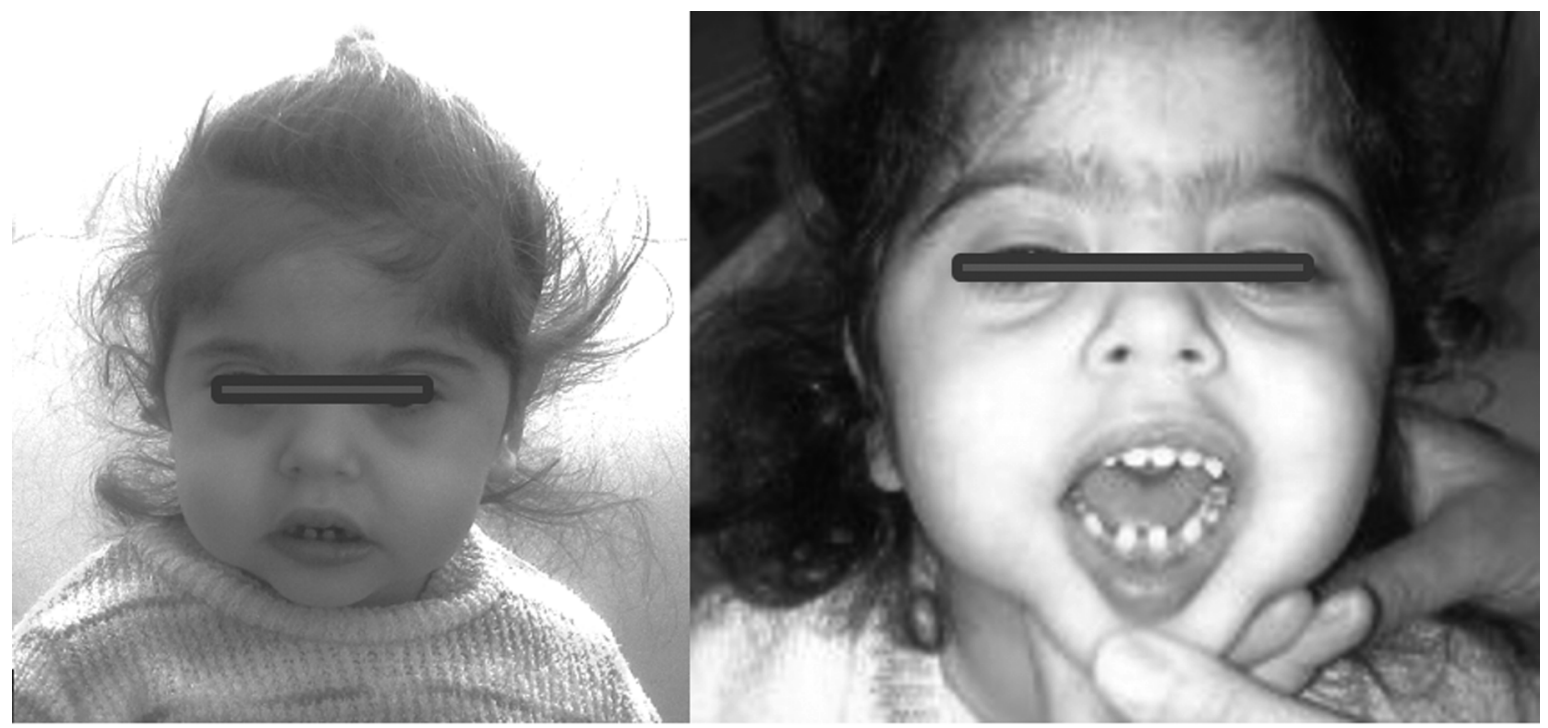

Fig. 1. Facial appearence of the patient; (large lips, wide mouth, flat nasal bridge, broad nasal tip, epicanthal folds, long philtrum, eyes set apart, periorbital fullness, widely spaced teeth, delicate chin and mandibular hypoplasia, socalled elfin face). 
hours (normal $<4 \mathrm{mg} / \mathrm{kg} / 24$ hours), and the creatinine clearance was $25.5 \mathrm{ml} / \mathrm{min} / 1.73 \mathrm{~m}^{2}$. Parathormone and 25-hydroxyvitamin D levels were $42.1 \mathrm{pg} / \mathrm{ml}$ (normal: $3.6-32 \mathrm{pg} / \mathrm{ml}$ ) and $44 \mu \mathrm{g} / \mathrm{ml}$ (normal: 10-60 $\mu \mathrm{g} / \mathrm{ml}$ ). The spot urine $\mathrm{Ca} / \mathrm{Cr}$ ratio was found as 1.2 (normal $<0.5 \mathrm{mg} / \mathrm{mg}$ ). Spot urine evaluations showed normal oxalate excretion $(0.016 \mathrm{mmol} / \mathrm{mmol}$; normal: <0.09-0.1), hypocitraturia $(253 \mathrm{mg} / \mathrm{g}$ of creatinine, normal: $>400 \mathrm{mg}$ ) and normal urinary amino acids profils. We were not able to measure urinary beta2-microglobulin and perform urinary protein electrophoresis.

Laboratory data revealed a normal thyrotropin (TSH) level of $3.8 \mathrm{mIU} / \mathrm{ml}$ (normal range, 0.4 to 5.6 ) with a free thyroxine (FT4) of $0.96 \mathrm{ng} / \mathrm{dl}$ (normal range, 0.52 to 1.24 ) and a triiodothyronine (T3) of $4.1 \mathrm{pg} / \mathrm{ml}$ (normal range, 2.5 to 4.8 ). The skeletal survey and parathyroid scintigraphy were also normal. Abdominal ultrasonography of the patient showed severe nephrocalcinosis (Fig 2). Echocardiography was reported as mild supravalvular aortic stenosis. There were no abnormalities except for nephrocalcinosis on renal Doppler-ultrasonography. Fluorescence in-situ hybridization (FISH) analysis revealed a microdeletion in the elastin gene in the 7q11.23 region of the seventh chromosome, which was consistent with WBS. Intravenous fluid, furosemide administration $(0.1 \mathrm{mg} / \mathrm{kg} / \mathrm{h})$, prednisolone $(2 \mathrm{mg} / \mathrm{kg} /$ day $)$, and dietary $\mathrm{Ca}$ restriction $(400 \mathrm{mg} /$ day $)$ were started to treat the hypercalcemia. However, the patient's $\mathrm{Ca}$, $\mathrm{BUN}$, and $\mathrm{Cr}$ levels did not reduce to the normal range after 15 days of standard treatment and symptomatic hypercalcemia persisted. The patient then received 1-day intravenously administered pamidronate $(1 \mathrm{mg} / \mathrm{kg})$ over $6 \mathrm{~h}$. Although the level of Ca reduced from $16 \mathrm{mg} /$ dl to $14 \mathrm{mg} / \mathrm{dl}$, a second pamidronate infusion was given 1 week after the first dose because it still had not returned to the normal range. The follow-up Ca level was detected as 12 $\mathrm{mg} / \mathrm{dl}$ on the next day. Ca levels were found as $11.5,10.9$, and $10.2 \mathrm{mg} / \mathrm{dl}$, respectively on subsequent days. Renal function also gradually

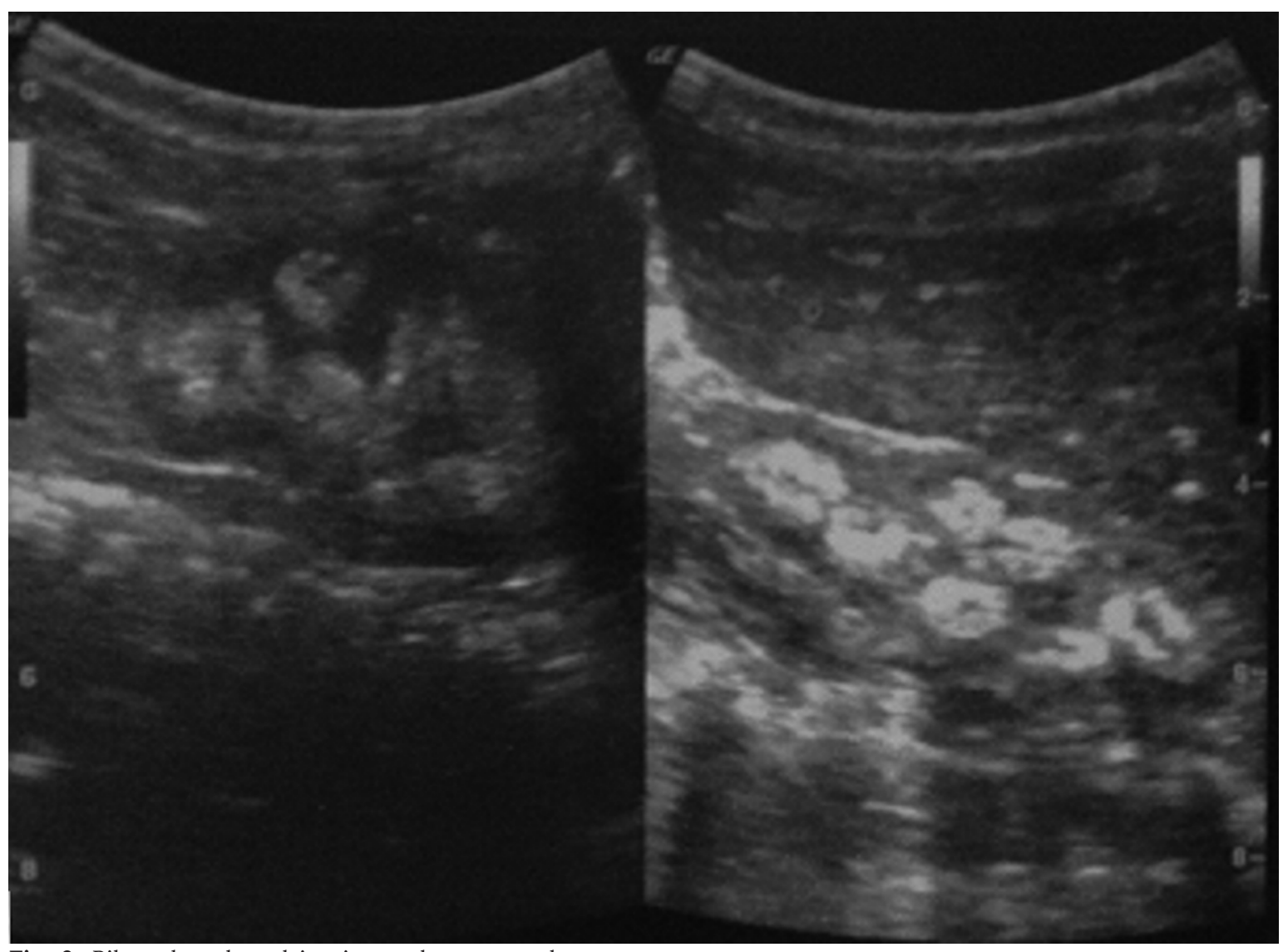

Fig. 2. Bilateral nephrocalcinosis on ultrasonography 
improved after serum calcium level was restored through pamidronate treatment. On the 30th day of admission the laboratory tests results were: serum Ca, $10.8 \mathrm{mg} / \mathrm{dl}$; BUN, $12 \mathrm{mg} / \mathrm{dl}$; $\mathrm{Cr}, 0.6 \mathrm{mg} / \mathrm{dl}$, venous $\mathrm{pH}$ was 7.43 ; HCO3: $24 \mathrm{mEq} / \mathrm{L}$ and spot urine $\mathrm{Ca} / \mathrm{creatinine}$ ratio was found as $0.53 \mathrm{mg} / \mathrm{mg}$. No adverse effect was detected after pamidronate treatment. The patient was discharged from hospital with a low $\mathrm{Ca}$ diet. At the last follow-up visit, she was aged 3 years and serum $\mathrm{Ca}, \mathrm{BUN}$, and $\mathrm{Cr}$ levels were found normal as 10. 8, 15 and 0.6 $\mathrm{mg} / \mathrm{dl}$, respectively with a moderately increased urinary $\mathrm{Ca} /$ creatinine ratio $(0.6 \mathrm{mg} / \mathrm{mg})$ and nephrocalcinosis on an unrestricted diet. Early intervention education was initiated with good results. She gained milestones but was still significantly behind her peers. At the age of 3 years, our patient remained developmentally delayed, especially in the intellectual and speech facilities. She also showed significant delays in gross motor skills such as walking. Participation involved informed consent.

\section{Discussion}

Williams-Beuren syndrome was first reported as idiopathic hypercalcemia in 1952, then independently described by Williams et al. in 1961, and Beuren et al. in 1962 as a disorder involving unusual facial features, supravalvular aortic stenosis, and mental retardation. ${ }^{1}$

Although infantile hypercalcemia is a wellknown sign of WBS, the cause of hypercalcemia is unclear. The proposed mechanisms of hypercalcemia include; vitamin D sensitivity, increased 1.25-dihydroxy vitamin D levels and defective calcitonin synthesis or release. ${ }^{1,4,10}$ Most studies investigated to find changes in vitamin $\mathrm{D}$ metabolism. Some reports find abnormalities in all WBS patients, whereas others only describe changes in vitamin $D$ metabolism in WBS patients with hypercalcemia, and some groups find no changes at al. ${ }^{4}$

An episode of hypercalcemia can be asymptomatic or associated with nonspecific symptoms such as feeding problems, irritability, constipation and hypotonia but occasionally can be severe and life-threatening5-8. Sometimes persistent abnormalities of calcium metabolism can result in hypercalciuria and nephrocalcinosis ${ }^{4}$. Hypercalciuria generally accompanies hypercalcemia but isolated hypercalciuria especially after infancy can also occur. ${ }^{1,4}$ Nephrocalcinosis is relatively rare, found in less than $5 \%$ of patients undergoing renal ultrasonography. ${ }^{11}$

Hypercalcemia generally improves spontaneously or can be treated with traditional therapies such as restriction of dietary calcium, hydration, diuretics and steroids in most patients with WBS. $^{1,4}$ Severe hypercalcemia in patients with WBS might rarely need additional therapy such as bisphosphonates. Pamidronate like other bisphosphonates is used successfully in treating hypercalcemia associated with various disorders because it acts on bone to reduce osteoclast resorption. ${ }^{12}$

However, there are only a few reports in the literature regarding the use of pamidronate in hypercalcemia associated with WBS. ${ }^{5-8}, 13$ Oliveri et $a .^{5}$ reported the first description of successful treatment of WS-associated hypercalcemia with intravenously administered pamidronate in a 14-months-old boy. The patient' s Ca level was $13 \mathrm{mg} / \mathrm{dl}$ and was treated with one dose of $1 \mathrm{mg} / \mathrm{kg}$ pamidronate infusion over $4 \mathrm{~h}$. Then 2 days after this treatment, serum calcium diminished to normal levels and remained within normal range during one-year follow-up. Cagle et al. 6 reported three patients at the ages of 9, 11 and 13 months old with WS-associated hypercalcemia. The first patient's severe hypercalcemia (17.3 $\mathrm{mg} / \mathrm{dl}$ ) resolved with traditional therapies, whereas the subsequent 2 patients were treated with intravenously administered pamidronate after traditional measures. They reported that the second patient's Ca level was 17.7 $\mathrm{mg} / \mathrm{dl}$ and was treated with one dose of $1 \mathrm{mg} / \mathrm{kg}$ pamidronate infusion over $6 \mathrm{~h}$. However, the third patient with a Ca level of $13.5 \mathrm{mg} / \mathrm{dl}$ required additional pamidronate therapy at the same dosages at the age of 15 months, 20 months and 23 months. In a recent report from Turkey, Sangun et al. ${ }^{7}$ reported a 17-month-old female patient with WBS-associated hypercalcemia $(16.1 \mathrm{mg} / \mathrm{dl})$ were treated successfully with one dose of $1 \mathrm{mg} / \mathrm{kg}$ pamidronate and calcium levels returned to normal within 2 days. Another report from Ismail et al. ${ }^{8}$ reported a 3 yearold boy with WS-associated hypercalcemia $(14.5 \mathrm{mg} / \mathrm{dl})$ was treated with a single dose of $1 \mathrm{mg} / \mathrm{kg}$ intravenous pamidronate and 
the serum calcium levels decreased over a period of 3 days to $10.2 \mathrm{mg} / \mathrm{dl}$. In contrast to these studies, Lameris et al. ${ }^{13}$ reported an 18-month-old patient of WBS-associated severe symptomatic hypercalcemia. Despite mild calcium restriction, hyperhydration and repeated bisphosphonate treatment, long-term lowering of serum calcium was only achieved after reducing calcium and vitamin $\mathrm{D}$ intake to the basic minimum. The underlying cause was thought to be an intestinal cause because they sustained no effect of bisphosphonate treatment. They advocated that increased intestinal absorption of calcium is the main factor in the pathogenesis of hypercalcemia in this patient, potentially as a result of reduced breakdown of vitamin D. In our patient, similar to previous reports ${ }^{5-8}$, hypercalcemia was well controlled with pamidronate therapy. Even though we were not able to study $1.25-(\mathrm{OH})$ vitamin D levels, $25-\mathrm{OH}$ vitamin D study was normal in our patient likely a non-vitamin $\mathrm{D}$-mediated cause of the hypercalcemia.

Unlike other cases in addition to hypercalcemia, nephrocalcinosis was also accompanied by acute renal failure in our case. Symptomatic hypercalcemia was successfully treated with two infusions of pamidronate no adverse effects such as hypocalcemia, were observed. Although the acute renal failure did not improve with hydration, renal function normalized following recovery of hypercalcemia with the pamidronate infusions. It is known that nephrocalcinosis may cause deterioration of renal function, which leads to tubular damage and/or tubular obstruction. ${ }^{14}$ We also considered a diagnosis of tubulointerstitial nephritis in our patient despite not having taken a renal biopsy because she had signs clinically suggestive of a tubulointerstitial pathology, non-oliguric renal failure and deteriorating renal tubular function tests. We were not able to measure urinary beta2-microglobulin and perform urinary protein electrophoresis. It was a limitation on evaluating all tubular functions.

It has been reported in several case reports that chronic renal failure secondary to congenital renal anomalies can develop in patients with WBS, but decreased renal function secondary to nephrocalcinosis has been reported only once. In that report, Pober et al. ${ }^{15}$ published renal findings of 40 patients with an age distribution of 0-4 years $=20 ; 5-9$ years $=10$; $10-14$ years $=5$ and $>15$ years $=5$ (average age at time of evaluation $=72 / 12$ years) cases with WBS. They noted transient renal failure secondary to nephrocalcinosis in a boy aged 18 months, similar to our patient.

To our knowledge, this is the fifth report in the literature to demonstrate the effect of pamidronate infusions in the treatment of severe hypercalcemia associated with WBS and it is the first report of recovery from acute renal failure secondary to nephrocalcinosis following the improvement of hypercalcemia after pamidronate treatment. It is our consideration that the renal failure improved because of the decrease in tubulointerstitial damage owing to the reduction of hypercalcemia and hypercalciuria after pamidronate infusions.

Intravenous pamidronate seems to be a reasonable way of treating life-threatening hypercalcemia in patients with WBS. Referral to a nephrologist is recommended for patients with WBS who have persistent hypercalcemia and/or hypercalciuria or nephrocalcinosis.

\section{REFERENCES}

1. Pober BR. Williams-Beuren syndrome. N Engl J Med 2010; 362: 239-252.

2. Martens MA, Wilson SJ, Reutens DC. Research Review: Williams syndrome: a critical review of the cognitive, behavioral, and neuroanatomical phenotype. J Child Psychol Psychiatry 2008; 49: 576-608.

3. Eronen M, Peippo M, Hiippala A, et al. Cardiovascular manifestations in 75 patients with Williams syndrome. J Med Genet 2002; 39: 554-558.

4. Kruse K, Pankau R, Grosch A, Wohlfahrt K. Calcium metabolism in Williams-Beuren syndrome. J Pediatr 1992; 121: 902-907.

5. Oliveri B, Mastaglia SR, Mautalen C, Gravano JC, Pardo Argerich L. Long-term control of hypercalcaemia in an infant with Williams-Beuren syndrome after a single infusion of biphosphonate (pamidronate). Acta Paediatr 2004; 93: 1002-1003.

6. Cagle AP, Waguespack SG, Buckingham BA, Shankar RR, Dimeglio LA. Severe infantile hypercalcemia associated with Williams syndrome successfully treated with intravenously administered pamidronate. Pediatrics 2004; 114: 1091-1095.

7. Sangun O, Dundar BN, Erdogan E. Severe hypercalcemia associated with Williams syndrome successfully treated with pamidronate infusion therapy. J Pediatr Endocr Metab 2011; 24: 69-70.

8. Ismail J. Pamidronate for long-term control of hypercalcemia associated with Williams syndrome. Indian Pediatr 2015; 52:163-164. 
9. Sugayama SMM, Koch VH, Furusawa EA, Leone C, Kim CA. Renal and urinary findings in 20 patients with Williams-Beuren syndrome diagnosed by fluorescence in situ hybridization (FISH). Sugayama. Rev Hosp Clín Fac Med Sao Paulo 2004; 59: 266-272.

10. Chambellan-Tison C, Horen B, Plat-Wilson G, Moulin P, Claudet I. Severe hypercalcemia due to vitamin D intoxication. Arch Pediatr 2007; 14: 1328-1332.

11. Sforzini C, Milani D, Fossali E, et al. Renal tract ultrasonography and calcium homeostasis in WilliamsBeuren syndrome. Pediatr Nephrol 2002; 17: 899-902.
12. Somalo L, Santos F. Clinical use of bisphosphonates in children. World J Pediatr 2007; 3: 245-253.

13. Lameris AL, Geesing CL, Hoenderop JG, Schreuder MF. Importance of dietary calcium and vitamin D in the treatment of hypercalcaemia in Williams-Beuren syndrome. J Pediatr Endocrinol Metab 2014; 27: 757761.

14. Sayer JA, Carr G, Simmons NL. Nephrocalcinosis: molecular insights into calcium precipitation within the kidney. Clin Sci (Lond) 2004; 106: 549-561.

15. Pober BR, Lacro RV, Rice C, Mandell V, Teele RL. Renal findings in 40 individuals with Williams syndrome. Am J Med Genet 1993; 46: 271-274. 